\title{
Better Regulation: Holding Martin Selmayr Accountable
}

This time was supposed 'to be different', at least this was the motto of the 2014 European Parliament elections campaign. With less than a year before the next European elections, the time is ripe to examine how different this EU political cycle has actually been.

Emboldened by the Spitzenkandidaten process - which established for the first time a link between the outcome of the EU elections and the presidency of the EU Commission -, the Juncker Commission emerged as the most political yet. To shrug off the label of technocratic institution - historically insulated from citizens' preferences -, the new Commission asked EU citizens to judge its operation by its ability 'to deliver solutions to the big issues that cannot be addressed by the Member States alone'. By embracing such a panem et circenses approach to EU democracy - as such not too dissimilar from the Santer's and Barroso's previous administrations - the Juncker Commission raised new expectations. This is true not only in terms of output legitimacy - which was meant to become the privileged benchmark against which to measure the Commission's success -, but also in terms of its own democratic and political accountability vis-à-vis EU citizens. Indeed, although unintelligible to the many, the Spitzenkandidaten logic entails that EU citizens contributed for the first time with their vote to shape the political orientation of this Commission and - as a result - could hold it accountable. While the very notion of political accountability is foreign to the EU constitutional setting - as citizens don't have the possibility to replace the Commission if this does not meet their hopes -, the Juncker Commission has strived to frame its mandate as if such an oversight existed.

To turn this vision into action, the Juncker Commission revived the so called Better Regulation Agenda, a rather obscure, legally fuzzy initiative launched in 2002 with the declared aim 'to simplify and improve the regulatory environment' and set to ensure that the Commission will remain 'big on big things, small on small things'. By choosing Better Regulation - which consists of a set of analytical tools, such as Impact Assessment, open to participatory input - as its privileged, accountability-enhancing tool, the Commission sought to identify a renewed optimal mix between the two major democratic legitimizing mechanisms of EU policymaking: representative democracy and participatory democracy. Yet, in so doing, it has inadvertently raised public expectations not only to the whats (output accountability) but also to the who's (input accountability) and hows (throughput accountability) of EU policy-making. 


\section{Input Accountability}

When it comes to input accountability, the Better Regulation Agenda has further expanded the opportunities for stakeholder engagement, without however tapping into the democratic potential of bottom-up participatory processes. Indeed, despite the multiplication in recent years of the avenues of participation available to citizens and other stakeholders - ranging from the European Citizens' Initiative (ECI) to public consultations, including the Lighten the Load and the REFIT Platform - to shape EU policy-making, the dominant EU participatory model embraced by the Juncker Commission remains shaped by the neo-corporatist legacy. As such, it favours organised interests over grassroots input and - as exemplified by the absence of a European Administrative Procedure Act (or an equivalent) it denies procedural rights to influence decision-making. While Better Regulation institutionalised public participation, it fell short of providing a corresponding proceduralisation, as suggested by Article 11 TFEU. This inherently restrains the ability of the EU to pluralise its policymaking.

Due to its self-proclaimed 'political' nature, the Juncker Commission seems to perceive any suggestion to depart from its agreed agenda as a source of distraction - or even a threat - from delivering on its original political programme. Yet this is a missed opportunity insofar as participatory procedures may provide citizens with agenda-setting - as well as monitoring - powers that could complement not antagonise - the dominant legitimising force of EU democracy: representative democracy. Here's an illustration. The 2018 Stop Glyphosate's ECI symbolises the disconnect between the supposedly participatory nature of EU policymaking and its actual techno-political basis. It shows that while EU citizens have been attributed the power to contribute to agenda-setting in the EU, via the collection of 1 million signatures in support of - or against - a given initiative, their stance has no official bearing - nor institutional linkage to - on an ongoing decision-making process, such as that of re-authorisation of a substance on the market. If what the $\mathrm{ECI}$ demands and the political preferences of the EU Commission might differ on a given issue, such a tension explodes and become manifest when the latter preferences are not only part of a political programme but are also the object of an ongoing political bargaining. In such circumstances, the Commission finds itself in a situation of conflict of interest: on the one hand, in the exercise of its own prerogatives - be they legislative or non-legislative - is called upon to propose the course of action or policy option - that it deems more appropriate, on the other, it is responsible for determining whether an $\mathrm{ECl}$ seeking the opposite outcome can be registered and then, if successful, deserve a follow-up. Yet, in the absence of an institutional bridge, the participatory process (e.g. hearing of $\mathrm{ECl}$ ) and the decision-making process (e.g. adoption of a legislative or non-legislative act) are like ships that pass at night. How to then expect stakeholders to meaningfully engage with EU decision-making? 


\section{Throughput Accountability}

The Better Regulation Agenda has been devised and managed by the EU Commission Secretariat-General. As such it has not been embraced to the same degree within and beyond the Commission's walls. The different level of commitment to Better Regulation can be detected both at the pre-legislative phase - among the Commission's Directorates-General - and at the legislative phase, by the colegislators, i.e. the Parliament and the Council. When it comes to the pre-legislative phase, Better Regulation has been used not only as a quality-enhancing tool in the preparation of new or revised initiatives, but also and foremost as an instrument of control. Thus, legislative (e.g. the non-toxic environment strategy, the endocrine strategy and new environmental action programme) and non-legislative (e.g. implementing measure on roaming charges) proposals have been withdrawn, whereas others - despite not being in the political guidelines (e.g. plastics strategy and controls on single-use plastic) - have been let in. When it comes to the legislative phase instead, the asymmetric commitment to Better Regulation by the initiator (the Commission) and the adopters (the Parliament and the Council) of EU policies was meant to be overcome by the conclusion of the Inter-Institutional Agreement on Better Law-making. While this new agreement has led to a better coordination upstream of the policy process - with the three institutions defining annual lists of priority proposals - and increased the quality and transparency of the pre-legislative process, this has not translated into an acceleration in the rate of adoption of Commission proposals by the co-legislators. Moreover, if the Better Regulation Agenda has increased the scope for holding the EU Commission accountable for its operation - by both the public and the co-legislators - it has not necessarily been used towards such an objective.

\section{Output Accountability}

As originally announced, the most immediate effect of the Juncker's Better Regulation Agenda has been a dramatic decrease of policy output. Based on the ten priorities of the Juncker Commission, the Commission has succeeded in having $48 \%$ of its proposals adopted, with peaks of $100 \%$ for its proposals related to 'A Strong Global Actor' and lows of $25 \%$ in relation to 'A deeper and fairer economic and monetary union': 25\% (Adopted: 3, Pending: 9).

When it comes to output accountability, the major commitment of the Juncker Commission has been to connect its ex-post analysis system - aimed at verifying whether adopted legislation remains fit for purpose - to the public, via the Regulatory Fitness and Performance Platform. While this newly-created platform is made by both Member States and civil society organisations' representatives, it is tasked to invite, collect and assess suggestions from all stakeholders - through the Lighten the Load platform - "on how to reduce regulatory and administrative burden". The platform's operation suggests however that it is not the public but the REFIT 
Platform members who drive the process; a process which is in turn led by the EU Commission itself in a highly-framed, top-down operation. As such, the overall increase of the accountability over the legislative output appears modest.

\section{Conclusions}

To sum up, the Better Regulation Agenda might have improved the Commission's public accountability - with both citizens and stakeholders being better informed about and engaged with EU policy-making -, without however increasing its responsiveness to public preferences. This is the case at the input, throughput and output stage. Rather, the techno-political approach to policymaking - which characterizes the Juncker's Better Regulation - might have paradoxically led to a compression of participatory democracy and somehow chilled stakeholder engagement. At a time of unprecedented contestation of the EU project - a trend which is combined by a record-demand for new forms of political representation -, it appears paradoxical that the EU - an early promoter of participation - is missing out the chance to seize the momentum to diversify and redesign its participatory structures being busy delivering on its electoral promises no one will ever judge.

At the very same time the Juncker Commission has been striving to develop its own, autonomous democratic credentials, its choice to embrace a set of well-defined institutional mechanisms that reward expert judgment over political adjudication appears at odds with its newly-acquired political nature.

PS 1: An official assessment of the Better Regulation Agenda is expected to be published by the first quarter of 2019 .

PS 2: It won't escape the reader's attention that - despite its subtitle - this piece does not focus on Martin Selmayr's role in devising the Better Regulation strategy. It suffices to say that Mr Selmayr originally devised such a strategy - as the chief of staff of President Juncker (together with Frans Timmermans, the First VicePresident of the Commission) -, to then become the guarantor of its implementation in his new, current role as Secretary-General of the EU Commission. Ironically, the process that led Selmayr to move from one position to another was found by the EU Ombudsman "to stretch and possibly even overstretch the limits of the law" and as a result in breach - on four different accounts - of the principle of good administration. Far from signalling a triumph of Better Regulation within the EU Commission's administration, one must also notice that it is Martin Selmayr - in his new role of Secretary-General of the EU Commission - who found himself supervising the EU Ombudsman's investigation on his own actions. So much for the accountability of the EU administration vis-à-vis the public (!). To know more about the decision of the EU Ombudsman, this is available here. 
(cc) BY-NC-ND

- 5 - 